\title{
Impact Assessment of Smoking Duration on Polycyclic Aromatic Hydrocarbons (PAH's) Contaminations of Clarias gariepinus.
}

\author{
Abiona, O.O., Adegunwa, A.O., Awojide, S.H, Agbaje, W. B. and Tayo, A. S.
}

\begin{abstract}
Smoked catfish (Clarias gariepinus) was examined with the aim of determining the effect of smoking duration on the extent of accumulation of the sixteen US EPA priority polycyclic aromatic hydrocarbons (PAHs). The levels of PAHs in the smoked catfish samples were obtained using gas chromatography with a flame ionization detector after extracting with nhexane by soxhlet extraction technique. The result showed detection of all the 16 PAHs in the smoked catfish. Higher molecular weight PAHs having $\geq 4$ rings showed considerably higher concentration as compared to PAHs that had a lower ring. The mean concentrations of total $\mathrm{PAH}$ in the investigated smoked catfish showed mean values of $1.91 \mu \mathrm{g} / \mathrm{kg}, 2.10 \mu \mathrm{g} / \mathrm{kg}, 2.32$ $\mu \mathrm{g} / \mathrm{kg}, 2.58 \mu \mathrm{g} / \mathrm{kg}$ respectively. The $\Sigma \mathrm{BaPeq}(0.113)$ and $\Sigma \mathrm{PAH}(10.642 \mu \mathrm{g} / \mathrm{kg})$ levels are within the range of European Commission Regulations maximum tolerable limits of 2 to $5 \mu \mathrm{g} / \mathrm{kg}$ respectively. The result indicated that the $\mathrm{PAH}$ accumulation is directly proportional to the smoking period. Diagnostic ratio (Ant/(Ant+Phen) ratio $<0.10)$ conducted showed wood combustion as the main sources of contamination in the analyzed smoked catfish.
\end{abstract}

Keywords: smoked catfish, gas chromatograph, carcinogenic potency, polycyclic aromatic hydrocarbon and smoking duration

\section{Introduction}

Food processing usually involves thermal treatments at high temperature. The direct contact with combustion gases have different effects on the nutritional compositions of food due to the intensity and directness of heat transfer from the source to the food [1], this governs the rate and extent of polycyclic aromatic hydrocarbons (PAHs) formation especially in protein products. PAHs are group of persistent environmental pollutants that have their origins from incomplete combustion of organic compounds and pyrolysis of fatty foods. They have known carcinogens and a quite number of researches

Abiona, O.O. (Department of Food Science and Technology, Osun State University, Osogbo, Nigeria)

Adegunwa, A.O, Awojide, S.H, Agbaje, W. B. and Tayo,

A. S. (Department of Pure and Applied Chemistry,

Osun State University, Osogbo, Nigeria)

Corresponding author: oluseye.abiona@uniosun.edu.ng

Phone Number: +234 have been conducted due to their ability to cause cancer and mutagenicity to humans [2].

The United State Environmental Protection Agency (USEPA) had listed PAHs as priority organic pollutants; this is as a result of their persistent nature and high toxicity potency [3]. The persistency of PAHs in many environmental matrixes is owed to their relative chemical stability as well as resistance to biodegradation. Literatures have shown that human exposure to PAHs could promote prevalence of deadly diseases such as lung and skin cancers among others [4].

Though there are many parameters that govern the formation of PAHs in foods and fatty tissues, they do not work individually but they are all inter-reactive. These factors include the nature of the cooking surface, time of cooking, temperature, water as well as the composition of the food [5].

High protein food such as fish has been observed to form more mutagenic products 
than starchy foods, these show that there is a direct link with the lipid content indicating the ability of PAHs to bio-accumulate in tissues of fat-based foods [6]. On heating proteins, high molecular weight PAHs that are highly carcinogenic are formed and these by-products have been known to act as direct mutagens which may also play the role of cocarcinogens or activators [3].

Several methods have been proposed for risk assessment characterization of PAH in food, the commonest of which is the use of $\mathrm{BaP}$ as markers using the toxicity equivalent factor (TEF) of benzo(a)pyrene in other PAHs. This is as a result of potential carcinogenicity nature of benzo(a)pyrene which happened to be a known PAH with the extensive toxicological fact [7].

Report has it that regular consumption of smoked and grilled foods could promote a significant increase in uptake of PAH into the body system [8]. Based on this fact, considerable attention has been on traditionally smoked food items to ascertain the level of PAH accumulation after processing under substantial heat. Exposure of protein foods to smoke has the capacity to increases the accumulation of PAHs in the food tissues than other secondary methods where the processed food items are shielded from a direct application of heat [7].

Fish is considered as one of the proteins mostly consumed in this part of the world as a result of its palatability, flavour and cheap availability [9]. Fish has high protein retention in the body; it contains some bioactive compounds that give health benefits to human [10]. However, report has it that approximately $70 \%$ of $\mathrm{PAHs}$ are ingested orally through food items and this include the popular smoked fish [11].

This study, therefore, aims at estimating the rate of PAHs accumulation of smoked catfish at different smoking intervals. It also gives the probable carcinogenic health risk which could be associated with the consumption of such locally processed fish commonly consumed in Nigeria.

\section{Materials and Methods}

\section{A. Sampling}

Fresh catfish (about $2.5 \mathrm{~kg}$ ) were bought from local fish sellers in Osogbo, Osun State, Nigeria. A representative sample was obtained by pooling together the various fish samples from the different dealers. After cleaning, the raw fish was smoked with hardwood charcoal at a distance of $15 \mathrm{~cm}$ on a wire gauze. The smoking temperature was measured with a mercury-in-glass thermometer and smoking was done for a period of $8 \mathrm{~h}$ at a temperature range of $70-80{ }^{\circ} \mathrm{C}$ per day for 5 days. Every day after 8 hours of drying two of the fish samples was removed and made to cool. About $100 \mathrm{~g}$ of the smoked samples were pulverized and sealed in a labelled aluminium foil wrap. It was then refrigerated at $-20^{\circ} \mathrm{C}$ before analysis.

\section{B. Sample Preparation}

Soxhlet extraction technique with n-hexane as solvent was used to extract PAHs from the fish samples in a timble. Ten (10) grams of pulverized sample was weighed and stirred continuously with anhydrous sodium sulphate $(5 \mathrm{~g})$ in a crucible. The extract obtained was concentrated with the aid of a rotary evaporator. To prevent oxidation, the extract was refrigerated in an amber bottle. The method was repeated for other samples obtained for other smoking periods [7].

\section{Sample Purification}

Column chromatography cleaned up was achieved by passing the extract through a column (1 cm internal diameter) packed with 
activated silica gel adsorbent of about 100-200 mesh size to $5 \mathrm{~cm}$. This was covered with anhydrous $\mathrm{Na}_{2} \mathrm{SO}_{4}$ to about $1 \mathrm{~cm}$ and conditioned with $\mathrm{n}$-hexane. $2 \mathrm{ml}$ of the extracted PAHs was loaded and eluted with $20 \mathrm{ml}$ of $\mathrm{n}$-hexane. The eluant was collected into amber bottles to prevent oxidation before taken for analysis.

\section{GC-FID Analysis}

PAHs analysis was done using Agilent GC 7890A. Helium was the carrier gas flowing at a rate of $0.45 \mathrm{~mL} / \mathrm{min}$. sample injection was in the splitless mode with an injection volume of $2 \mu \mathrm{L}$. The $\mathrm{GC}$ oven temperature program was optimized: the initial temperature at $70^{\circ} \mathrm{C}$ was held for $2 \mathrm{~min}$ and then ramped at $10^{\circ} \mathrm{C} / \mathrm{min}$ to $220^{\circ} \mathrm{C}$. It was maintained at this temperature till the end of the run (33 $\mathrm{min})$. The injection port temperature was set at $250^{\circ} \mathrm{C}$ and that of the FID detector was set at $300^{\circ} \mathrm{C}$. The hydrogen and airflow rates were set at $40 \mathrm{~mL} / \mathrm{min}$ and $400 \mathrm{~mL} / \mathrm{min}$, respectively.

\section{E. BaP Equivalent}

The estimate of the relative toxicity of individual PAH fraction compared to benzo (a) pyrene is termed a toxicity equivalency factor (TEF). This approach revealed the probable health risk associated with the consumption of the food materials as a function of benzo(a)pyrene equivalent. This was obtained by multiplying the individual PAHs values with their TEF [7].

$$
B a P=\Sigma B a P=\Sigma C_{P A H i} \times T E F_{P A H i}
$$

$\mathrm{C}_{\mathrm{PAHi}}$ : values of $\mathrm{PAH}$ in the sample,

$\mathrm{TEF}_{\mathrm{PAH}}$ : Toxic equivalency factor for each PAH.

\section{F. Statistical Analysis of Data}

Triplicate analysis of the PAH was done for each sample. The obtained results were statistically analysed using SPSS (version 20.0) windows software. Standard error of the mean concentration (SEM) was calculated for each parameter.

\section{Result and Discussion}

\section{A. Mean Concentrations $(\mu \mathrm{g} / \mathrm{L})$ of PAHs in the Smoked Catfish Samples}

Results of the mean concentrations of the analyzed 16PAHs in the smoked catfish at different smoking time intervals using GCFID are displayed in Table 1 showing the targeted PAHs detected in the analyzed smoked catfish samples while the cumulative PAHs concentration as smoking duration increases as shown in figure 1. From the results, it was observed that fluorene, phenanthrene, pyrene acenaphthylene, acenaphthene and fluoranthene, showed predominant values in the samples. Also, phenanthrene revealed higher $\mathrm{PAH}$ concentration in the chosen smoking time intervals.

Molecular weight was used to categorize the set of analysed PAHs. High molecular weight were benzo(k)fluoranthene, benzo(a)anthracene, indeno(1,2,3-cd)pyrene, benzo(b)fluoranthene, benzo(4a)pyrene benzo(ghi)perylene, anthranthrene and Chrysene. The medium molecular weights are fluoranthene and pyrene while the low molecular weights are naphthalene, acenaphthylene, acenaphthene, fluorene, anthracene and phenanthrene. The total mean concentrations of $0.948 \mu \mathrm{g} / \mathrm{kg}, 0.614 \mu \mathrm{g} / \mathrm{kg}$ and $0.105 \mu \mathrm{g} / \mathrm{kg}$ were recorded values for PAHs of high molecular weight, medium molecular weight and low molecular weight respectively. 
Table 1: Total mean concentration $(\mu \mathrm{g} / \mathrm{kg})$ of PAHs in smoked catfish muscle at different smoking intervals

\begin{tabular}{|c|c|c|c|c|c|}
\hline PAHs & S1 & $\mathrm{S} 2$ & S3 & S4 & S5 \\
\hline Naphthalene & $0.021 \pm 0.001$ & $0.022 \pm 0.001$ & $0.028 \pm 0.002$ & $0.029 \pm 0.001$ & $0.035 \pm 0.020$ \\
\hline Acenaphthylene & $0.139 \pm 0.005$ & $0.168 \pm 0.002$ & $0.173 \pm 0.005$ & $0.159 \pm 0.001$ & $0.196 \pm 0.001$ \\
\hline Acenaphthene & $0.054 \pm 0.002$ & $0.057 \pm 0.001$ & $0.067 \pm 0.001$ & $0.076 \pm 0.010$ & $0.080 \pm 0.005$ \\
\hline Fluorene & $0.135 \pm 0.001$ & $0.150 \pm 0.020$ & $0.158 \pm 0.001$ & $0.161 \pm 0.004$ & $0.208 \pm 0.025$ \\
\hline Phenanthrene & $0.233 \pm 0.010$ & $0.283 \pm 0.012$ & $0.310 \pm 0.002$ & $0.344 \pm 0.002$ & $0.352 \pm 0.012$ \\
\hline Anthracene & $0.182 \pm 0.003$ & $0.187 \pm 0.050$ & $0.212 \pm 0.001$ & $0.243 \pm 0.010$ & $0.281 \pm 0.010$ \\
\hline Fluoranthene & $0.104 \pm 0.001$ & $0.315 \pm 0.100$ & $0.358 \pm 0.004$ & $0.410 \pm 0.005$ & $0.439 \pm 0.100$ \\
\hline Pyrene & $0.154 \pm 0.028$ & $0.200 \pm 0.050$ & $0.256 \pm 0.003$ & $0.332 \pm 0.001$ & $0.303 \pm 0.005$ \\
\hline Benzo(a)anthracene & $0.002 \pm 0.001$ & $0.003 \pm 0.001$ & $0.004 \pm 0.001$ & $0.004 \pm 0.001$ & $0.005 \pm 0.001$ \\
\hline Chrysene & $0.006 \pm 0.001$ & $0.007 \pm 0.002$ & $0.008 \pm 0.001$ & $0.009 \pm 0.004$ & $0.009 \pm 0.001$ \\
\hline Benzo(b)flouranthene & $0.004 \pm 0.001$ & $0.004 \pm 0.001$ & $0.006 \pm 0.002$ & $0.006 \pm 0.001$ & $0.007 \pm 0.002$ \\
\hline Benzo(k)flouranthene & $0.010 \pm 0.005$ & $0.011 \pm 0.001$ & $0.013 \pm 0.002$ & $0.016 \pm 0.001$ & $0.019 \pm 0.001$ \\
\hline Benzo(a)pyrene & $0.059 \pm 0.003$ & $0.061 \pm 0.001$ & $0.063 \pm 0.002$ & $0.071 \pm 0.014$ & $0.075 \pm 0.015$ \\
\hline Indeno(1,2,3-cd)pyrene & $0.002 \pm 0.001$ & $0.003 \pm 0.001$ & $0.003 \pm 0.001$ & $0.004 \pm 0.001$ & $0.004 \pm 0.001$ \\
\hline $\operatorname{Dibenzo}(a, h)$ anthracene & $0.035 \pm 0.001$ & $0.036 \pm 0.012$ & $0.039 \pm 0.001$ & $0.044 \pm 0.002$ & $0.054 \pm 0.001$ \\
\hline Benzo(g,h,i)perylene & $0.001 \pm 0.001$ & $0.002 \pm 0.001$ & $0.003 \pm 0.001$ & $0.007 \pm 0.002$ & $0.009 \pm 0.001$ \\
\hline$\sum 16 \mathrm{PAH}$ & 1.741 & 1.909 & 2.101 & 2.315 & 2.576 \\
\hline
\end{tabular}

Smoking intervals S1 $=5$ hrs, S2 = 10 hrs, S3 = 15 hrs, S4 = 20 hrs and S5 = 25 hrs

The maximum tolerable limits by European Union for benzo(a)pyrene and total PAHs in the muscle of smoked fish and other fishery products were given as $2.0 \mu \mathrm{g} / \mathrm{kg}$ and 10 $\mu \mathrm{g} / \mathrm{kg}$ respectively by EU [12]. The report observed for the concentrations of Benzo[a]Pyrene (BaP) and total PAHs observed in Niger delta area of Nigeria at different smoking intervals were below the range of 1.5 and $10.5 \mu \mathrm{g} \mathrm{kg}{ }^{-1}$ [2]. However, this study showed a considerably higher concentration of $\mathrm{BaP}$ at $5.205 \times 10^{-4} \mu \mathrm{g} / \mathrm{kg}$ in the long-processed fish samples.

Mean chrysene and Benzo(b)fluoranthene, pyrene and indenol(1,2,3-cd)pyrene concentrations were similar $(\mathrm{P}>0.05)$ as the smoking duration increases which shows that they were no PAH accumulation these set of PAH during the smoking process.

The Agency for Toxic Substances and Disease Registry [13] reported that the levels of the sum of PAHs between 0 and $0.1 \mu \mathrm{g} / \mathrm{kg}$ are considered as slight contamination while values within the range of 0.1 to $1 \mu \mathrm{g} / \mathrm{kg}$ is an indication of significant contamination. This study showed a total concentration of PAHs within 1.741 and $2.576 \mu \mathrm{g} / \mathrm{kg}$ which implies a significant contamination

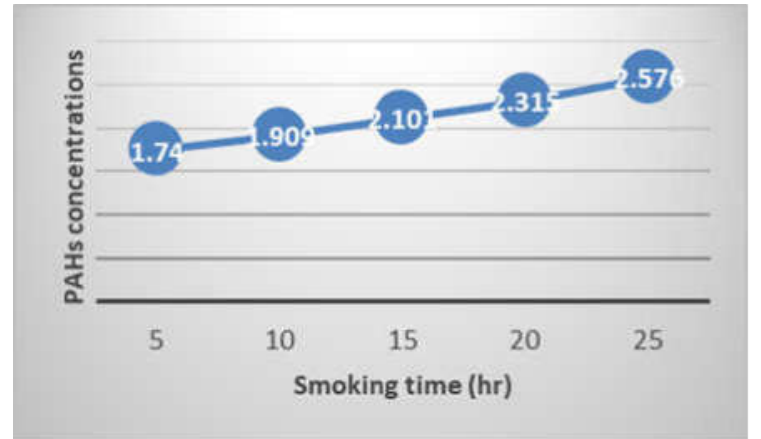

Figure 1: Concentrations of PAHs in smoked catfish muscle at different smoking intervals

\section{B. BaP Equivalent of PAHs in the Analyzed Smoked Catfish Samples}

The estimation of the carcinogenic impact of PAHs on the investigated smoke fish with the aid of toxicity equivalent factor (TEF) relative to benzo(a) pyrene was presented in Table 2. The total $\mathrm{BaP}$ equivalent (BaPeqi) was 0.113.

\section{Comparison of the PAH concentration in the Smoked Catfish with similar studies}

Though the values of $\mathrm{PAH}$ in smoked fish depends greatly on the type of wood used in smoking, the period of smoking and the temperature of smoking. However, it has been reported that there is a correlation between lipids and accumulation of PAHs [14], these compounds found its way on the surface of processed food materials (mostly 
fatty tissues) when exposed to heat as a result of high temperature involved during processing which in the long run leads to the buildup of PAHs on the surface of the protein products [17].

Table 2. Toxic Equivalent Factors (TEFs) and $\mathrm{BaP}$ Equivalent of PAHs in the Smoked Catfish

\begin{tabular}{lrcr}
\hline \multicolumn{1}{c}{ PAHs } & Concentration & TEF & BaP $_{\text {eqi }}$ \\
\hline Naphthalene & $0.035 \pm 0.020$ & 0.001 & - \\
Acenaphthylene & $0.196 \pm 0.001$ & 0.001 & 0.0001 \\
Acenaphthene & $0.080 \pm 0.005$ & 0.001 & 0.0001 \\
Fluorene & $0.208 \pm 0.025$ & 0.001 & 0.0002 \\
Phenanthrene & $0.352 \pm 0.012$ & 0.001 & 0.0003 \\
Anthracene & $0.281 \pm 0.010$ & 0.01 & 0.0022 \\
Fluoranthene & $0.439 \pm 0.100$ & 0.001 & 0.0004 \\
Pyrene & $0.303 \pm 0.005$ & 0.001 & 0.0003 \\
Benzo(a)anthracene & $0.005 \pm 0.001$ & 0.1 & - \\
Chrysene & $0.009 \pm 0.001$ & 0.01 & 0.0008 \\
Benzo(b)flouranthene & $0.007 \pm 0.002$ & 0.1 & - \\
Benzo(k)flouranthene & $0.019 \pm 0.001$ & 0.1 & 0.0014 \\
Benzo(a)pyrene & $0.075 \pm 0.015$ & 1.0 & 0.0066 \\
Indeno(1,2,3-cd)pyrene & $0.004 \pm 0.001$ & 0.1 & - \\
Dibenzo(a,h)anthracene & $0.054 \pm 0.001$ & 1.0 & 0.0410 \\
Benzo(g,h,i)perylene & $0.009 \pm 0.001$ & 0.001 & - \\
\hline$\sum 16 \mathrm{PAH}$ & 2.576 & 2.428 & 0.113 \\
\hline
\end{tabular}

Table 3: PAH Isomer Ratios of Sampled Smoked Catfish

\begin{tabular}{lllllll}
\hline $\begin{array}{l}\text { Sampl } \\
\text { e/Iso } \\
\text { mer } \\
\text { ratio }\end{array}$ & $\begin{array}{l}\text { Phe } \\
\text { n/A } \\
\text { nt }\end{array}$ & $\begin{array}{l}\text { An/ } \\
\text { An+ } \\
\text { Phe }\end{array}$ & $\begin{array}{l}\text { Flu/ } \\
\text { Flu+ } \\
\text { Phe }\end{array}$ & $\begin{array}{l}\text { Na } \\
\mathbf{p} / \mathbf{P} \\
\text { he }\end{array}$ & $\begin{array}{l}\text { BaA/ } \\
\text { BaA+ } \\
\text { Ch }\end{array}$ & $\begin{array}{l}\text { Ind/I } \\
\text { nd+B } \\
\text { ghiP }\end{array}$ \\
\hline S1 & 1.28 & 0.439 & 0.403 & 0.09 & 0.25 & 0.667 \\
& 0 & & & 0 & & \\
S2 & 1.51 & 0.398 & 0.612 & 0.07 & 0.30 & 0.600 \\
& 3 & & & 8 & & \\
S3 & 1.46 & 0.406 & 0.538 & 0.09 & 0.33 & 0.571 \\
& 2 & & & 0 & & \\
S4 & 1.41 & 0.414 & 0.553 & 0.08 & 0.31 & 0.363 \\
& 6 & & & 4 & & \\
S5 & 1.25 & 0.444 & 0.592 & 0.09 & 0.36 & 0.285 \\
& 3 & & & 9 & & \\
\hline Total & 6.92 & 2.101 & 2.698 & 0.44 & 1.550 & 2.486 \\
& 4 & & & 1 & & \\
\hline
\end{tabular}

Table 4 showed the comparison of the distribution of total mean PAHs in the smoked catfish of this present study with findings from related studies [15]. Similar observations detected high PAHs concentrations in catfish $(69.645 \mu \mathrm{g} / \mathrm{kg})$ and tilapia fish $(42.115 \mu \mathrm{g} / \mathrm{kg})$ respectively in which naphthalene showed the highest concentrations in both samples [15]. The result of this study also agrees with some other findings on the effect of cooking methods on food materials [16].

Table 4: Comparison of the PAH $(\mu \mathrm{g} / \mathrm{kg})$ concentration in this study with other related studies

\begin{tabular}{|c|c|c|c|c|}
\hline PAHs & $\begin{array}{l}\text { Abbr } \\
\text { ev. }\end{array}$ & $\begin{array}{c}\text { This } \\
\text { Study } \\
\text { (Catfish) }\end{array}$ & $\begin{array}{c}{[15]} \\
\text { (Catfish } \\
\text { ) }\end{array}$ & $\begin{array}{c}15] \\
\text { (Tilapia } \\
\text { ) }\end{array}$ \\
\hline Naphthalene & Nap & $\begin{array}{c}0.035 \pm 0 \\
.020\end{array}$ & $\begin{array}{c}68.966 \pm \\
0.423\end{array}$ & $\begin{array}{c}41.447 \pm \\
0.006\end{array}$ \\
\hline $\begin{array}{l}\text { Acenaphthyle } \\
\text { ne }\end{array}$ & Acy & $\begin{array}{c}0.196 \pm 0 \\
.001\end{array}$ & $\begin{array}{c}0.008 \pm 0 \\
001\end{array}$ & $\begin{array}{c}0.132 \pm 0 . \\
003\end{array}$ \\
\hline $\begin{array}{l}\text { Acenaphthen } \\
\mathrm{e}\end{array}$ & Ace & $\begin{array}{c}0.080 \pm 0 \\
.005\end{array}$ & $\begin{array}{c}0.384 \pm 0 \\
036\end{array}$ & $\begin{array}{c}0.328 \pm 0 \\
013\end{array}$ \\
\hline Fluorene & Flu & $\begin{array}{c}0.208 \pm 0 \\
.025\end{array}$ & $\begin{array}{c}0.058 \pm 0 . \\
002\end{array}$ & $\begin{array}{c}0.052 \pm 0 . \\
003\end{array}$ \\
\hline $\begin{array}{l}\text { Phenanthren } \\
\mathrm{e}\end{array}$ & Phe & $\begin{array}{c}0.352 \pm 0 \\
.012\end{array}$ & $\begin{array}{c}0.060 \pm 0 \\
001\end{array}$ & $\begin{array}{c}0.049 \pm 0 . \\
001\end{array}$ \\
\hline Anthracene & Ant & $\begin{array}{c}0.281 \pm 0 \\
.010\end{array}$ & $\begin{array}{c}0.058 \pm 0 . \\
001\end{array}$ & $\begin{array}{c}0.048 \pm 0 . \\
003\end{array}$ \\
\hline Fluoranthene & Fla & $\begin{array}{c}0.439 \pm 0 \\
.100\end{array}$ & $\begin{array}{c}0.012 \pm 0 . \\
002\end{array}$ & $\begin{array}{c}0.010 \pm 0 . \\
001\end{array}$ \\
\hline Pyrene & Pyr & $\begin{array}{c}0.303 \pm 0 \\
.005\end{array}$ & $\begin{array}{c}0.005 \pm 0 \\
001\end{array}$ & $\begin{array}{c}0.003 \pm 0 \\
001\end{array}$ \\
\hline $\begin{array}{l}\text { Benzo(a)anth } \\
\text { racene }\end{array}$ & $\mathrm{BaA}$ & $\begin{array}{c}0.005 \pm 0 \\
.001\end{array}$ & $\begin{array}{c}0.003 \pm 0 \\
001\end{array}$ & $\begin{array}{c}0.003 \pm 0 . \\
001\end{array}$ \\
\hline Chrysene & Chr & $\begin{array}{c}0.009 \pm 0 \\
.001\end{array}$ & $\begin{array}{c}0.002 \pm 0 \\
001\end{array}$ & $\begin{array}{c}0.002 \pm 0 \\
001\end{array}$ \\
\hline $\begin{array}{l}\text { Benzo(b)flou } \\
\text { ranthene }\end{array}$ & $\mathrm{BbF}$ & $\begin{array}{c}0.007 \pm 0 \\
.002\end{array}$ & $\begin{array}{c}0.005 \pm 0 . \\
001\end{array}$ & $\begin{array}{c}0.003 \pm 0 . \\
001\end{array}$ \\
\hline $\begin{array}{l}\text { Benzo(k)flou } \\
\text { ranthene }\end{array}$ & $\mathrm{BkF}$ & $\begin{array}{c}0.019 \pm 0 \\
.001\end{array}$ & $\begin{array}{c}0.005 \pm 0 . \\
001\end{array}$ & $\begin{array}{c}0.003 \pm 0 . \\
002\end{array}$ \\
\hline $\begin{array}{l}\text { Benzo(a)pyre } \\
\text { ne }\end{array}$ & $\mathrm{BaP}$ & $\begin{array}{c}0.075 \pm 0 \\
.015\end{array}$ & $\begin{array}{c}0.040 \pm 0 . \\
030\end{array}$ & $\begin{array}{c}0.004 \pm 0 . \\
002\end{array}$ \\
\hline $\begin{array}{l}\text { Indeno(1,2,3- } \\
\text { cd)pyrene }\end{array}$ & IcdP & $\begin{array}{c}0.004 \pm 0 \\
.001\end{array}$ & $\begin{array}{c}0.014 \pm 0 . \\
001\end{array}$ & $\begin{array}{c}0.013 \pm 0 . \\
002\end{array}$ \\
\hline $\begin{array}{l}\operatorname{Dibenzo}(\mathrm{a}, \mathrm{h}) \\
\text { anthracene }\end{array}$ & $\begin{array}{c}\text { Dah } \\
\text { A }\end{array}$ & $\begin{array}{c}0.054 \pm 0 \\
.001\end{array}$ & $\begin{array}{c}0.011 \pm 0 . \\
001\end{array}$ & $\begin{array}{c}0.008 \pm 0 . \\
002\end{array}$ \\
\hline $\begin{array}{l}\text { Benzo }(g, h, i) p \\
\text { erylene }\end{array}$ & $\begin{array}{l}\text { Bghi } \\
\text { P }\end{array}$ & $\begin{array}{c}0.009 \pm 0 \\
.001\end{array}$ & $\begin{array}{c}0.014 \pm 0 . \\
001\end{array}$ & $\begin{array}{c}0.010 \pm 0 . \\
003\end{array}$ \\
\hline$\sum \mathrm{mPAH}$ & & 2.576 & 69.645 & 42.115 \\
\hline
\end{tabular}

\section{Conclusion}

The result of the study indicates the presence of sixteen priorities PAH. The PAHs concentration ranged between $1.74-2.58$ $\mu \mathrm{g} / \mathrm{kg}$. It was also observed that the value of PAHs in the samples increased progressively from day 1 to 5 with varied mean concentration from $1.74-2.58 \mu \mathrm{gg} / \mathrm{kg}$ suggesting that more PAHs are accumulated as smoking period lengthen. This could be due to thermal breakdown of lignin in lignocelluloses. Also, the result indicated that the polycyclic aromatic hydrocarbon contamination source may possibly emanate 
from wood combustion due to Ant/(Ant+Phen) ratio which is $>0.10$.

The average total PAH level of smoked catfish $(2.576 \mu \mathrm{g} / \mathrm{kg})$ was lower than the findings of some researchers who also studied the effect of smoking on the accumulation of PAHs on catfish and tilapia fish and obtained mean concentrations of $69.645 \mu \mathrm{g} / \mathrm{kg}$ and tilapia fish $42.115 \mu \mathrm{g} / \mathrm{kg}$ for catfish and tilapia fish respectively [15]. The result of this work revealed that the accumulation of PAHs by the catfish samples is directly proportional to smoking duration showing increasing order of total PAHs concentrations.

In conclusion, the smoked fish from this work is fit for consumption since the total PAHs falls within $2-5 \mu \mathrm{g} / \mathrm{kg}$ set by the European Commission as a tolerable limit but due to increase in $\mathrm{PAH}$ levels as smoking temperature and duration rises, there is a possibility of the PAH level exceeding the tolerable limit.

\section{References}

[1] Moret, S., Purcaro, G. and Conte, L.S. "Polycyclic Aromatic Hydrocarbons in Vegetable Oils from Canned Foods", European Journal Lipid Science Technology, vol. 107, 2005, pp. 488-496.

[2] Anyakora, C. and Coker, H. "Assessment of Polynuclear Aromatic Hydrocarbon Content in Four Species of Fish in the Niger Delta by Gas Chromatography/Mass Spectrometry", African Journal of Biotechnology, vol. 6, 2007, pp. 737-743.

[3] Yurchenko, S. and Molder, U. "The Determination of Polycyclic Aromatic Hydrocarbons in Smoked Fish by Gas Chromatography Mass Spectrometry with Positive-ion Chemical Ionization", Journal of Food Composition and Analysis, vol. 18, no. 8, 2005, pp. 857-869.

[4] Stumpe-Viksna, I., Bartkevics, V., Kuka' re, A. and Morozovs, A. "Polycyclic Aromatic

Hydrocarbons in Meat Smoked with Different Types of Wood", Food Chem, vol. 110, 2008, pp. 794-797.
[5] Duedahl-Olesenm, L., White, S. and Binderup, M.L. "Polycyclic Aromatic Hydrocarbons (PAH) in Danish Smoked Fish and Meat Products", Polycycl Aromat Comp, vol. 26, 2006, pp. 163-184.

[6] CCFAC. "Codex Committee on Food Additives and Contaminants", Discussion paper on polycyclic aromatic hydrocarbons contamination. 37th Session, The Hague, the Netherlands, 2005.

[7] Abiona, O.O., Adegunwa, A.O. and Awojide, S. H. "Polycyclic Aromatic Hydrocarbons (PAHs) Contamination Profile of Barbequed Meats in Some Selected Selling Points within Osogbo, Nigeria", Acta Scientific Nutritional Health, vol. 3, no. 9, 2019, pp. 181-187.

[8] Kazerouni, N., Sinha, R., Hsu, C.H., Greenberg, A. and Rothman, N. "Analysis of 200 Food Items for Benzo(a)pyrene and Estimation of its Intake in an Epidemiologic Study", Food and Chemical Toxicology, vol. 39, 2001, pp. 423-436.

[9] Foran, J.A; Carpenter, D.O., Hamilton, M.C., Knuth, B.A and Schwager, S.J. "Risk-based Consumption Advice for Farmed Atlantic and wild Pacific Salmon Contaminated with Dioxins and Dioxin-like Compounds", Environ. Health Perspect, vol. 33, 2005, pp. 552-556.

[10] Anthony, O.R and Akinwumi, J.A "Supply and Distribution of Fish in Ibadan, Nigeria", Geo. J, vol. 4, no. 2, 1991, pp. 16.

[11] Nnaji, J.C., Okoye, F.C. and Omeje, V.O. "Screening of Leaf Meals as Feed Supplements in the Culture of Oreochromis Niloticus", Afr. J. Food Agric. Nutr. Dev, vol. 10, no. 2, 2010, pp. 2112-2123.

[12] European Food Safety Authority EFSA Scientific Committee on Food. Opinion on the risks to human health of polycyclic aromatic hydrocarbons in food, Italy, 2002.

[13] Agency for Toxic Substance and Disease Registry (ATSDR), "Toxicological Profile for Persistent Organic Pollutants", Atlanta, GA: U.S. Department of Health and Human Service, 2005.

[14] Akpan, V., Lodovici, M. and Dolara, P. "Polycyclic Aromatic Hydrocarbons in Fresh and Smoked Fish Samples from the Three Nigerian Cities" Bull. Environ. Contam. Toxicol., vol. 53, 1994, pp. 246-253.

[15] Nnaji, J.C. and Ekwe, N.P. "Effect of Smoking on Polycyclic Aromatic Hydrocarbons 
(PAH) Concentrations in Catfish and Tilapia muscles", Journal of Applied Science and Environmental management, vol. 22, no 2. 2018, pp. 293 - 294.

[16] Reinik, M., Tamme, T., Roasto, M., Juhkam, K., Tenno, T. and Kus, A. "Polycyclic Aromatic Hydrocarbons (PAHs) in Meat Products and Estimated PAH Intake by Children and the General Population in Estonia", Food Additives and Contaminants, vol. 24, no. 4, 2007, pp. 429-437.

[17] Ujowundu, C.O., Ihekweazu, K.L., Alisi, C.S., Ujowundu, F.N and Igwe, C.U. "Procarcinogens: Polycyclic Aromatic Hydrocarbons and Heavy Metal Content in Some Locally Processed Foods in South Eastern Nigeria. Brit. J. Appl. Sc. Technol, vol. 4, no. 1, 2014, pp. 249-260. 